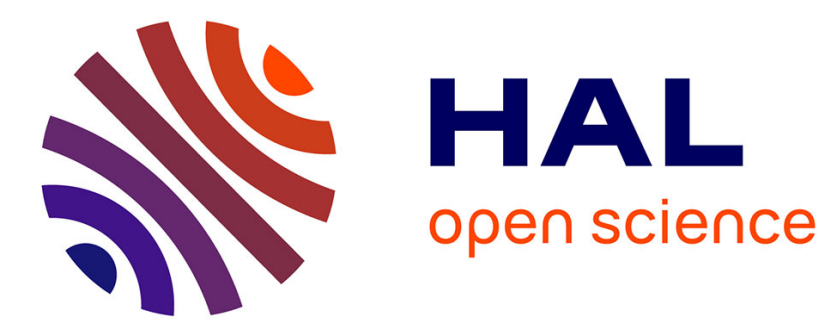

\title{
Cover crops and organic amendments to prevent nitrate contamination under a wet climate
}

\author{
M. Vidal, A. López
}

\section{To cite this version:}

M. Vidal, A. López. Cover crops and organic amendments to prevent nitrate contamination under a wet climate. Agronomy for Sustainable Development, 2005, 25 (4), pp.455-463. hal-00886292

\section{HAL Id: hal-00886292 \\ https://hal.science/hal-00886292}

Submitted on 1 Jan 2005

HAL is a multi-disciplinary open access archive for the deposit and dissemination of scientific research documents, whether they are published or not. The documents may come from teaching and research institutions in France or abroad, or from public or private research centers.
L'archive ouverte pluridisciplinaire HAL, est destinée au dépôt et à la diffusion de documents scientifiques de niveau recherche, publiés ou non, émanant des établissements d'enseignement et de recherche français ou étrangers, des laboratoires publics ou privés. 


\title{
Cover crops and organic amendments to prevent nitrate contamination under a wet climate
}

\author{
M. VIDAL ${ }^{\text {a* }}$, A. LÓPEZ \\ ${ }^{a}$ Escuela Superior y Técnica de Ingeniería Agraria, Universidad de León, Av. de Portugal 41, E-24071 León, Spain \\ ${ }^{\mathrm{b}}$ Escuela Politécnica Superior, Universidad de Santiago de Compostela, Campus Universitario, E-27002 Lugo, Spain
}

(Accepted 12 May 2005)

\begin{abstract}
The efficiency of a rye cover crop as a preventive measure for nitrate contamination in water resources was assessed in field tests. The study region (Galicia, NW Spain), which is severely affected by this environmental impact, has an annual average precipitation markedly exceeding the evapotranspiration level. Two additional corrective measures (viz. buried wheat and lupin green manure) were also studied in parallel. A randomized complete block experimental model spanning a period of three years was used to systematically determine the organic matter, total $\mathrm{N}, \mathrm{NO}_{3}^{-}-\mathrm{N}$ and $\mathrm{NH}_{4}^{+}-\mathrm{N}$ contents, and the $\mathrm{C} / \mathrm{N}$ ratio, in the $0-20$ and $20-40 \mathrm{~cm}$ soil layers. Based on the significance of the different effects examined in the variance explanation model (viz. the repeated measurements general linear model) as evaluated using multivariate comparisons, the rye treatment proved more efficient than the other two corrective practices at controlling $\mathrm{NO}_{3}^{-}$leaching from soil. By contrast, the application of the two plant residues to the soil exposed a priming effect induced by the simultaneous incorporation of mineral $\mathrm{N}$. The suppression of the individual effects of some variability sources revealed a clear fertilizing effect in the green manure and net immobilization resulting from the incorporation of straw into the soil.
\end{abstract}

contamination / nitrate / cover crops / green manure / straw / rye / lupin

\section{INTRODUCTION}

The preventive and corrective measures recommended by the FAO (1997) to avoid the agricultural contamination of water resources include the use of long-lasting plant covers and that of green manure during the post-harvest period. In this vein, the European Community has established a body of rules on agricultural practices to be followed with a view to reducing water contamination with agricultural nitrates. Council Directive 91/676/EEC (1991) launched an action program aimed at preventing and correcting their environmental impact that was to be implemented as a code of good farming practices by each Member State. Among other things, the Directive recommends the use of buried cereal straw, the sensible usage of nitrogen fertilizers, taking into account the amount of $\mathrm{N}$ produced by the mineralization of organic matter, the correct usage of plant covers and similar cultivation practices.

There is a wealth of information about the management of cover crops used after harvesting of main crops and their effects on aquatic systems (Addiscott et al., 1991; Paramasivan and Alva, 1997). The most desirable properties in a winter cover crop with a view to preventing the nitrate contamination of water resources are the ability to reduce $\mathrm{NO}_{3}^{-}-\mathrm{N}$ leaching from soil and to supply $\mathrm{N}$ to the next crop (Brinsfield and Staver, 1992). The former results from competition for soluble nitrate, which can be simultaneously leached and swept from soil. A number of grasses, crucifers and legumes have proved especially capable of recovering soluble and residual $\mathrm{N}$ from soil during autumn (Widdowson et al., 1987). Also, cover crops of non-legume plants have been found to control soluble $\mathrm{N}$ in soil roughly three times more efficiently than legumes. This increased efficiency is reflected both in a reduction in the total amount of $\mathrm{N}$ that is leached from soil - up to $70 \%$ on average with non-legume species - and in a decreased $\mathrm{NO}_{3}^{-}$concentration in the drainage water - which can be reduced by $50 \%$ on average with non-legumes (Holderbaum et al., 1990). The main reason behind the difference is the increased growth and dry matter production rates of non-legumes, which allow them to temporarily compete for $\mathrm{N}$ leached from soil. One non-legume species, rye, is among the most widely-used cover crops on account of its ability to immobilize and sequester nitrate ions thanks to its rapid root growth and dry matter production (Francis et al., 1994; Staver and Brinsfield, 1991).

One other measure aimed at lessening the impact of nitrate contamination on water resources involves facilitating the temporal immobilization of $\mathrm{NO}_{3}^{-}-\mathrm{N}$ forms by incorporating cereal straw into soil. Overall, the use of buried plant residues has provided widely variable results as regards $\mathrm{C}$ and $\mathrm{N}$ changes depending on the particular conditions of the tests and the specific nature of the residue (Haynes, 1986). Ever since Jansson (1958) established the theory of the continuous mineralizationimmobilization of soil $\mathrm{N}$, nitrogen turnover has repeatedly been

\footnotetext{
*Corresponding author: diamvb@unileon.es
} 
Table I. Annual fertilization programme used with each crop.

\begin{tabular}{|c|c|c|c|c|c|c|c|}
\hline \multirow[t]{2}{*}{ crop } & \multicolumn{2}{|c|}{ basal dressing } & \multicolumn{2}{|l|}{ top dresssing } & \multicolumn{3}{|c|}{ total $\left(\mathrm{kg} \mathrm{ha}^{-1}\right)$} \\
\hline & fertilizer & $\mathrm{kg} \mathrm{ha}^{-1}$ & fertilizer & $\mathrm{kg} \mathrm{ha}^{-1}$ & $\mathrm{~N}$ & $\mathrm{P}_{2} \mathrm{O}_{5}$ & $\mathrm{~K}_{2} \mathrm{O}$ \\
\hline Maize & $15-15-15$ & 1167 & Calcium ammonium nitrate, $26 \%$ & 96 & 200 & 175 & 175 \\
\hline Potato & $15-15-15$ & 800 & Calcium ammonium nitrate, $26 \%$ & 96 & 145 & 120 & 120 \\
\hline Wheat & $8-24-16$ & 375 & $\begin{array}{l}\text { 1-Calcium ammonium nitrate, } 26 \% \\
\text { 2-Calcium ammonium nitrate, } 26 \%\end{array}$ & $\begin{array}{l}135 \\
135\end{array}$ & 100 & 90 & 60 \\
\hline
\end{tabular}

found to be strongly altered by the incorporation of plant residues into soil. However, it was Doryland (1916) who hypothesized that the dynamics of the mineralization and immobilization processes depend on the energy/N ratio for the substrate applied. This allowed the subsequent establishment of the foundation for the decomposition of straw incorporated into soil (Konobeka and Sabbe, 1997). In fact, the process depends mainly on the content of $\mathrm{N}$ (Ocio et al., 1991), which is known to be available in adequate amounts for soil biomass (Andrén and Paustin, 1987). Some early tests (Lohnis, 1926) revealed that the addition of organic substrates could somehow boost $\mathrm{N}$ mineralization in soil.

Soil management tests conducted with a view to examining the underlying mechanisms of $\mathrm{N}$ turnover in soil should consider its water status. The mineralization rate of soil organic $\mathrm{N}$ is known to increase with increasing moisture between the permanent wilting point $(-1.5 \mathrm{MPa})$ and the field capacity ( -5 to $-19 \mathrm{KPa}$ ) (Van Gestel et al., 1993; Andrén et al., 1992). Similarly, repeated soil wetting-drying cycles favor mineralization as the successive episodes result in marked growth of edaphic biomass (Leon et al., 1995), which a number of authors have ascribed to a "priming effect" - a term introduced by Bingemann (1953) - of mineralization (Powlson et al., 1988).

The priming effect essentially involves the alteration of the mineralization rate of organic matter in soil upon the incorporation of an organic substrate. The final outcome can be an enhancing or suppressing effect, or can be reflected in marked changes in the organic matter cycle over very short periods under the effect of moderate soil treatments (Kuzyakov et al., 2000). A number of mechanisms have been put forward to account for the increased mineralization of organic $\mathrm{C}, \mathrm{N}$ and $P$ under the influence of a priming effect (Chapman, 1997). Studies on $\mathrm{C}$ turnover have led some authors to believe that the priming effect essentially involves additional decomposition of organic $\mathrm{C}$ upon addition of easily decomposed organic substances to soil. However, the difficulty of monitoring this effect, even with C and N isotopes (Dalemberg and Jager, 1989; Kuderayoz et al., 1987), has led to its redefinition as an apparent priming effect (Haynes, 1986).

The primary aim of this work was to examine the efficiency of the above-described farming practices in an area of NW Spain with an average annual precipitation above $1400 \mathrm{~mm}$ and an average potential evapotranspiration of $612 \mathrm{~mm}$. The interest in studying this humid area was enhanced by the fact that the region experiences episodes of scarce drinking water owing to severe nitrate contamination of its water resources over long periods (Vidal et al., 2000a, b). The study area is a sedimentary basin with heavy cattle breeding activity and substantial surpluses of bovine slurry that are normally applied to soil in fre- quent irrigation practices. It possesses a flat relief and a drainage network lying very near the ground surface. These factors, together with the impermeability provided by the underlying Miocene clay basement, facilitate flushing, flooding and surface runoff over large expanses of land bearing annual crops.

\section{MATERIALS AND METHODS}

\subsection{The study site}

The study was conducted in Galicia, a region in NW Spain with abundant rains in winter. Thus, about $70 \%$ of the mean annual precipitation, $1000 \mathrm{~mm}$, is collected in autumn and winter. Precipitation peaks in December and is minimal in July. These climatic conditions favor soil leaching and result in major nitrogen losses that pose serious surface water contamination problems on a regional scale. Temperatures are cool in winter and moderate throughout the rest of the year. The soils in the test plots were Oxyaquic Dystrudepts (USDA, 1999) and Gleyic-Arenic Umbrisols as per the FAO's WRB nomenclature (FAO, 1998). Each plot was $120 \mathrm{~m}^{2}$ in size and subjected to an annual sequence including a spring-winter crop followed by an autumn-winter treatment intended to alleviate nitrate leaching.

\subsection{Crops}

Three spring-winter crops typical of the study area were used, namely: wheat, maize and potato; the former was sown in February and the latter two were sown in May and cropped in late September. Each crop was supplied with appropriate fertilizer rates in accordance with the usual practices in the region (see Tab. I). The study included control plots that were neither cropped nor fertilized in the spring-winter period (bare soil), but only received the autumn-winter treatments. Each crop and its associated fertilizer represented a specific situation regarding soluble nutrient levels at harvest time and variable levels of potentially leachable nitrate in winter.

\subsection{Treatments}

The treatments for controlling the amount of nitrate in the drainage water were applied in early October each year. Such treatments included the use of rye (Secale cereale) as a cover crop, seeding green lupin (Lupinus albus L., cv Multolupa) manure and burial under chopped wheat straw. Rye was sown at a high density in order to facilitate the rapid growth of a plant cover and reaped and removed from the plots for simulated use as green fodder. The lupin crop was buried at the same time of 
year, which coincided with the pod development phenological stage; this crop supplied in the region of $5600 \mathrm{~kg} \mathrm{ha}^{-1}$ dry matter to the soil. The amounts of buried straw used the first, second and third year were 4000, 2000 and $5000 \mathrm{~kg} \mathrm{ha}^{-1}$; the straw was previously chopped into $5-10 \mathrm{~cm}$ pieces.

\subsection{Experiment establishment}

The experimental design involved the use of each of the three treatments on each crop and the control with three combined replications each; this required the use of a total of 36 plots. The characteristics of the test field led us to adopt a randomized complete block design.

The experiment lasted three years: from October 1999, when the initial treatments were applied to the original soil, to June 2002, after the treatments applied for the third and last time had been carried out. Each test plot was subjected to the same croptreatment sequence throughout the experiment. These control plots received none of the three crops (bare soil); in fact, they were only subjected to the different organic treatments.

\subsection{Experiment control}

The experiment was monitored by analyzing the soil in each plot in samples collected with the aid of a drill. Each sample consisted of five sub-samples that were randomly obtained from each plot. Samples were collected from the whole Umbric horizon $\left(A_{h}\right)$, which was split into two depths for this purpose: 0-20 and $20-40 \mathrm{~cm}$. The sampling operations were conducted immediately before crop establishment and soil treatment (i.e. in May and October). The system studied was assumed to be in a transitional stage during the first year, so no samples were collected until the second treatment was applied (May 2001). Samples were also collected in October 2001 and May 2002.

\subsection{Laboratory methods}

Table II shows the dry matter composition of the straw and lupin added to the soil. Organic carbon was determined by using the dry combustion method (Tiessen et al., 1981); total $\mathrm{N}$ by the Kjeldahl method; and the $\mathrm{P}, \mathrm{Ca}, \mathrm{Mg}, \mathrm{Na}$ and $\mathrm{K}$ contents by atomic spectrophotometry following calcination at $450{ }^{\circ} \mathrm{C}$ and dissolution of the resulting ash in $\mathrm{HCl}$.
Table II. Mineral composition of the plant residues. Contents are given in $\mathrm{g} \mathrm{kg}^{-1}$ dry matter. OC: organic carbon.

\begin{tabular}{lccccccccc}
\hline & $\begin{array}{r}\text { d.m. } \\
(\%)\end{array}$ & OC & $\mathrm{N}$ & $\mathrm{C} / \mathrm{N}$ & $\mathrm{P}$ & $\mathrm{Ca}$ & $\mathrm{Mg}$ & $\mathrm{K}$ & $\mathrm{Na}$ \\
& 97.1 & 399 & 5.1 & 78.2 & 1.0 & 2.7 & 0.8 & 10.9 & 1.8 \\
Straw & 21.3 & 401 & 38.2 & 10.5 & 4.8 & 7.0 & 2.6 & 29.3 & 4.3 \\
Lupin & 21.3 & & & & & & & &
\end{tabular}

Table III shows the properties of the initial soil (López, 2001). The $\mathrm{pH}$ in water and $1 \mathrm{~N} \mathrm{KCl}$ (both in a 1:2.5 soil/water suspension) were determined. Organic carbon was determined by wet digestion (Nelson and Sommers, 1982) and total $\mathrm{N}$ using the Kjeldahl method. The amount of moisture retained at a pressure of $1 / 3$ and 15 atm was measured in a Richards pressure chamber (Klute, 1986). The $\mathrm{NO}_{3}^{-}$and $\mathrm{NH}_{4}^{+}$concentrations were estimated from the second derivative of the UV absorption spectrum (Sempere et al., 1993) and by the use of an ionselective electrode (Keeney and Nelson, 1982), respectively. $\mathrm{NO}_{3}^{-}-\mathrm{N}$ and $\mathrm{NH}_{4}^{+}-\mathrm{N}$ were extracted with $0.01 \mathrm{M} \mathrm{CaCl}_{2}$ and $0.01 \mathrm{M} \mathrm{KCl}$, respectively. Exchangeable $\mathrm{Ca}, \mathrm{Mg}, \mathrm{Na}$ and $\mathrm{K}$ were extracted with $1 \mathrm{~N} \mathrm{NH}_{4} \mathrm{OAc}$ at $\mathrm{pH} 7$ according to Peech and Alexander (1947). The effective cation exchange capacity $\left(\mathrm{CEC}_{\mathrm{e}}\right)$ was determined from the combination of exchangeable bases and exchangeable acidity in $1 \mathrm{M} \mathrm{KCl}$. The percent base saturation, $\mathrm{V}$, was obtained from the combination of the $\mathrm{Ca}$, $\mathrm{Mg}, \mathrm{Na}$ and $\mathrm{K}$ contents, and the effective cation-exchange capacity.

\subsection{Statistical methods}

The results were statistically processed in terms of two independent variables or between-subject factors, namely: Treatment, at three levels (rye, straw and lupin), and Crop, at four levels (the three types of crop plus the control). In addition, the randomized complete block design included a new, within-subject factor: Block or Repetition. The fact that data were obtained at two different depths on three successive dates introduced two new sources of variability, namely: the within-subject factors Depth (at two levels) and Date (at three). Analyses of variance relied on a factor design including the principal effects of all within- and between-subject factors, and their potential interactions of order up to the fourth. Analyses were performed by using the Repeated Measurements General Linear Model (McCullagh and Nelder, 1983), which combines multivariate

Table III. General characterization of the soil. $d_{\mathrm{b}}$ bulk density, $d_{\mathrm{p}}$ particle density; wc percent gravimetric water content; CECe effective cation exchange capacity; $\mathrm{V}$ base saturation in $1 \mathrm{M} \mathrm{NH}_{4} \mathrm{OAc}$ at $\mathrm{pH}$.

\begin{tabular}{|c|c|c|c|c|c|c|c|c|c|c|c|}
\hline horiz. & $\begin{array}{l}\text { depth } \\
\mathrm{cm}\end{array}$ & $\begin{array}{c}\text { sand } \\
\%\end{array}$ & $\begin{array}{l}\text { silt } \\
\%\end{array}$ & $\begin{array}{c}\text { clay } \\
\%\end{array}$ & $\begin{array}{c}\mathrm{pH} \\
\text { water }\end{array}$ & $\begin{array}{l}\mathrm{pH} \\
\mathrm{KCl}\end{array}$ & $\begin{array}{l}\text { color } \\
\text { (moist) }\end{array}$ & $\begin{array}{c}d_{\mathrm{b}} \\
\mathrm{g} / \mathrm{cm}^{3}\end{array}$ & $\underset{\mathrm{g} / \mathrm{cm}^{3}}{d_{\mathrm{p}}}$ & $\begin{array}{c}\% \text { wc } \\
(1 / 3 \mathrm{~atm})\end{array}$ & $\begin{array}{c}\% \mathrm{wc} \\
(15 \mathrm{~atm})\end{array}$ \\
\hline$A_{h}$ & $0-40$ & 50.2 & 31.2 & 18.6 & 5.2 & 4.2 & 7,5YR 1/1 & 1.17 & 2.52 & 24.6 & 14.7 \\
\hline $\mathrm{B}_{\mathrm{w}}$ & $40-85$ & 50.6 & 26.7 & 22.7 & 5.3 & 4.2 & 10YR 5/6 & 1.76 & 2.75 & 18.7 & 10.4 \\
\hline horiz. & $\begin{array}{l}\text { depth } \\
\mathrm{cm}\end{array}$ & & & $\begin{array}{l}\text { Total-N } \\
\mathrm{g} \mathrm{kg}^{-1}\end{array}$ & $\mathrm{C} / \mathrm{N}$ & $\begin{array}{c}\text { E.C. (1:5) } \\
\mathrm{dS} \mathrm{m}^{-1}\end{array}$ & $\begin{array}{r}\text { CEC } \\
\operatorname{cmol}(+)\end{array}$ & & $\begin{array}{l}\mathrm{V} \\
\%\end{array}$ & $\begin{array}{l}\mathrm{NO}_{3}^{-}-\mathrm{N} \\
\mathrm{mg} \mathrm{kg}^{-1}\end{array}$ & $\begin{array}{l}\mathrm{NH}_{4}^{+}-\mathrm{N} \\
\mathrm{mg} \mathrm{kg}^{-1}\end{array}$ \\
\hline Ah & $0-40$ & & & 2.8 & 18.4 & 0.04 & 6.5 & & 16.3 & $\operatorname{tr}$ & 8 \\
\hline $\mathrm{Bw}$ & $40-85$ & & & 0.4 & 10.8 & 0.03 & 2.8 & & 37.6 & $\operatorname{tr}$ & 10 \\
\hline
\end{tabular}


analysis of variance and regression. The factor model, including the principal effects for all factors and all possible mutual interactions of order up to the fourth, was described by the following equation:

$$
\begin{gathered}
y_{i j k l}=\mu+\alpha_{i}+\beta_{j}+\gamma_{k}+\delta_{l}+\eta_{n}+[\alpha \beta]_{i j}+\ldots \\
+[\alpha \beta \gamma]_{i j k}+\ldots+[\alpha \beta \gamma \delta]_{i j k l}+\varepsilon_{i j k l}
\end{gathered}
$$

where $y_{i j k l}$ is the observed value; is the overall mean; $\alpha_{i}, \beta_{j}$, $\gamma_{k}, \delta_{l}$ and $\eta_{n}$ are the principal effects of the within- and betweensubject factors; $[\alpha \beta]_{i j}$, $[\alpha \beta \gamma]_{i j k}$ and $[\alpha \beta \gamma \delta]_{i j k l}$ denote the second-, third- and fourth-order interactions between the factors; and $\varepsilon_{i j k l}$ is the experimental or perturbation error as estimated from the residuals (viz. the differences between the observed and predicted values).

The different dependent variables simultaneously processed in the repeated measurement analysis of variance were obtained by repeating a measurement at different times (dates) or in different situations (depths) that constituted the within-subject factors. Both multivariate comparisons, between-subject effect tests and post hoc least significant difference (LSD) tests between observed means were performed. The $P$ value representing the significance of the effects was obtained from the $F$ value provided by Wilks' multivariate statistic. All computations were done by using the SPSS v. 11 statistical software package.

\section{RESULTS AND DISCUSSION}

From the data in Table III it follows that the studied soil was moderately acidic. The organic carbon content of the umbric horizon was high, but within the typical range for this humid Spanish area. Based on the $\mathrm{C} / \mathrm{N}$ ratio for the surface horizon, organic matter was poorly humified and evolved. The useful water content of the soil, expressed as the difference between its moisture contents at $1 / 3$ and 15 atm, was typical of an edaphic substrate with a low water-retention capacity. Also, the inorganic $\mathrm{N}$ content at the time of sampling was marginal. These results can be ascribed to the heavy precipitation of December 1999 (the time a prospecting pit was opened to characterize and initially sample the soil).

The analysis of the mineral composition of the buried plant residues (Tab. II) revealed increased contents of all elements constituting the dry matter of lupin. This was particularly so for $\mathrm{N}$ in this plant residue, the content of which was several times higher than that in the straw. As a result, the lupin exhibited a much lower $\mathrm{C} / \mathrm{N}$ ratio, which had a strong influence on changes in organic matter following burial of this plant residue.

The statistical treatment used exposed the significance of the different effects included in the variance explanation model as determined via multivariate comparisons. At a later stage, the least significant differences (LSD) of the post hoc tests for the factor Treatment were established (Tab. V). Table IV lists the

Table IV. Significance of the multivariate comparisons $(P)$ of the variables Crop (C), Treatment (T), Depth (DEP) and Date (D) and their double interactions for some chemical properties in the $3 \times 4$ groups established by combining the different levels of the factors Treatment (T) and Crop (C). O.M.: organic matter.

\begin{tabular}{lccccc}
\hline & O.M. & total-N & $\mathrm{C} / \mathrm{N}$ & $\mathrm{NO}_{3}^{-}-\mathrm{N}$ & $\mathrm{NH}_{4}^{+}-\mathrm{N}$ \\
\hline $\mathrm{C}$ & 0.550 & 0.329 & 0.411 & 0.000 & 0.150 \\
$\mathrm{~T}$ & 0.010 & 0.001 & 0.087 & 0.013 & 0.339 \\
$\mathrm{C} \times \mathrm{T}$ & 0.949 & 0.666 & 0.326 & 0.027 & 0.389 \\
$\mathrm{D}$ & 0.000 & 0.001 & 0.000 & 0.000 & 0.009 \\
$\mathrm{DEP}$ & 0.001 & 0.000 & 0.062 & 0.006 & 0.326 \\
$\mathrm{D} \times \mathrm{DEP}$ & 0.044 & 0.005 & 0.059 & 0.032 & 0.685 \\
$\mathrm{D} \times \mathrm{C}$ & 0.222 & 0.606 & 0.000 & 0.000 & 0.617 \\
$\mathrm{D} \times \mathrm{T}$ & 0.150 & 0.734 & 0.226 & 0.028 & 0.444 \\
$\mathrm{DEP} \times \mathrm{C}$ & 0.482 & 0.491 & 0.672 & 0.180 & 0.598 \\
$\mathrm{DEP} \times \mathrm{T}$ & 0.191 & 0.382 & 0.817 & 0.696 & 0.524 \\
\hline
\end{tabular}

Table V. Results of the post hoc tests for the factor Treatment (T). LSD between means of the observed values. Identical letters in each column

\begin{tabular}{|c|c|c|c|c|c|c|c|c|c|c|c|c|c|}
\hline \multirow{4}{*}{$\begin{array}{c}\text { O.M. } \\
\mathrm{mg} \mathrm{kg}^{-1}\end{array}$} & \multirow[b]{3}{*}{ Rye } & \multicolumn{6}{|c|}{ depth: 0-20 } & \multicolumn{6}{|c|}{ depth: $20-40$} \\
\hline & & \multicolumn{2}{|c|}{$05 / 2001$} & \multicolumn{2}{|c|}{$10 / 2001$} & \multicolumn{2}{|c|}{$05 / 2002$} & \multicolumn{2}{|c|}{$05 / 2001$} & \multicolumn{2}{|c|}{$10 / 2001$} & \multicolumn{2}{|c|}{$05 / 2002$} \\
\hline & & 73.3 & $\mathrm{a}$ & 84.3 & $\mathrm{a}$ & 76.7 & $\mathrm{a}$ & 67.9 & $\mathrm{a}$ & 82.6 & $\mathrm{a}$ & 72.9 & $\mathrm{a}$ \\
\hline & Straw & 77.4 & $\mathrm{a}$ & 86.5 & $\mathrm{a}$ & 87.8 & $\mathrm{~b}$ & 70.6 & $\mathrm{a}$ & 83.7 & a & 74.0 & a \\
\hline & Lupin & 84.7 & $\mathrm{~b}$ & 89.9 & $\mathrm{a}$ & 87.0 & $\mathrm{~b}$ & 71.1 & $\mathrm{a}$ & 88.5 & $\mathrm{a}$ & 91.9 & $\mathrm{~b}$ \\
\hline \multirow{3}{*}{$\begin{array}{c}\mathrm{N} \\
\mathrm{mg} \mathrm{kg}^{-1}\end{array}$} & Rye & 2.4 & $\mathrm{a}$ & 2.5 & $\mathrm{a}$ & 2.4 & $\mathrm{a}$ & 2.2 & $\mathrm{a}$ & 2.5 & $\mathrm{a}$ & 2.3 & a \\
\hline & Straw & 2.7 & $\mathrm{~b}$ & 2.7 & $\mathrm{ab}$ & 2.6 & $\mathrm{ab}$ & 2.4 & $\mathrm{a}$ & 2.5 & $\mathrm{a}$ & 2.3 & a \\
\hline & Lupin & 3.0 & $\mathrm{c}$ & 2.9 & $\mathrm{~b}$ & 2.7 & $\mathrm{~b}$ & 2.4 & $\mathrm{a}$ & 2.8 & $\mathrm{~b}$ & 2.7 & $b$ \\
\hline \multirow[t]{3}{*}{$\mathrm{C} / \mathrm{N}$} & Rye & 17.5 & $\mathrm{a}$ & 19.3 & $\mathrm{a}$ & 18.7 & $\mathrm{a}$ & 18.3 & $\mathrm{a}$ & 19.2 & $\mathrm{a}$ & 18.5 & $\mathrm{a}$ \\
\hline & Straw & 16.9 & $\mathrm{a}$ & 18.8 & $\mathrm{a}$ & 19.0 & $\mathrm{a}$ & 17.7 & $\mathrm{a}$ & 19.4 & $\mathrm{a}$ & 18.7 & $\mathrm{a}$ \\
\hline & Lupin & 16.7 & $\mathrm{a}$ & 18.2 & $\mathrm{a}$ & 18.4 & $\mathrm{a}$ & 17.7 & $\mathrm{a}$ & 18.1 & $\mathrm{~b}$ & 18.9 & $\mathrm{a}$ \\
\hline \multirow{3}{*}{$\begin{array}{c}\mathrm{NO}_{3}^{-} \\
\mathrm{mg} \mathrm{kg}^{-1}\end{array}$} & Rye & 39.3 & $\mathrm{a}$ & 78.1 & $\mathrm{a}$ & 23.2 & $\mathrm{a}$ & 30.1 & $\mathrm{a}$ & 54.7 & $\mathrm{a}$ & 27.8 & $a b$ \\
\hline & Straw & 43.4 & $\mathrm{a}$ & 89.3 & $\mathrm{a}$ & 28.4 & $\mathrm{a}$ & 29.8 & $\mathrm{a}$ & 54.4 & $\mathrm{a}$ & 26.0 & $\mathrm{a}$ \\
\hline & Lupin & 42.9 & $\mathrm{a}$ & 112.5 & $\mathrm{a}$ & 54.9 & $\mathrm{~b}$ & 34.1 & $\mathrm{a}$ & 86.2 & $\mathrm{~b}$ & 39.2 & $\mathrm{~b}$ \\
\hline \multirow{3}{*}{$\begin{array}{c}\mathrm{NH}_{4}^{+} \\
\mathrm{mg} \mathrm{kg}^{-1}\end{array}$} & Rye & 17.9 & $\mathrm{a}$ & 4.3 & $\mathrm{a}$ & 4.4 & $\mathrm{a}$ & 9.1 & $a b$ & 4.7 & $\mathrm{a}$ & 4.1 & $\mathrm{a}$ \\
\hline & Straw & 9.2 & $\mathrm{a}$ & 3.9 & $\mathrm{a}$ & 4.4 & $\mathrm{a}$ & 10.0 & $\mathrm{a}$ & 3.5 & $\mathrm{a}$ & 4.1 & $\mathrm{a}$ \\
\hline & Lupin & 8.7 & $\mathrm{a}$ & 4.1 & $\mathrm{a}$ & 4.7 & $\mathrm{a}$ & 7.5 & $\mathrm{~b}$ & 3.8 & $\mathrm{a}$ & 4.8 & $\mathrm{a}$ \\
\hline
\end{tabular}
denote non-significant differences at $P=0.05$. 
significance values for the multivariate comparisons of the variables Crop, Treatment, Depth and Date, as well as their double interactions in the $3 \times 4$ groups established from the combinations of the treatment and crop values. Note the influence or distinguishing power $(P=0.05)$ of the principal effect of the factor Treatment in relation to the organic matter content, total $\mathrm{N}$ and $\mathrm{NO}_{3}^{-}-\mathrm{N}$. The factor Date or seasonal variation was significant at the $P=0.05$ level for the five parameters considered. By contrast, the factor Crop was significant at the $P=0.05$ level for $\mathrm{NO}_{3}^{-}$only. This lack of significance of the factor Crop in relation to total $\mathrm{N}$, organic matter and the $\mathrm{C} / \mathrm{N}$ ratio can be ascribed to the alternative meaning of this factor, which ultimately involves the application of variable amounts of $\mathrm{N}$ fertilizer the latter as $\mathrm{NO}_{3}^{-}-\mathrm{N}$ or $\mathrm{NH}_{4}^{+}-\mathrm{N}$ (Tab. I). Consequently, it seems reasonable to assume that the factor Crop failed to discriminate the scores for the response variables except in those cases where it affected the inorganic $\mathrm{N}$ content. The within-subject factors Depth and sampling Date for the parameters organic matter, total $\mathrm{N}$ and $\mathrm{NO}_{3}^{-}-\mathrm{N}$ were also significant at $P=0.05$, and so was their interaction (Date $\times$ Depth). The significance of the factor Date at $P=0.05$ in relation to all the parameters studied reveals a strong seasonal influence of both the environmental conditions that govern $\mathrm{N}$ dynamics and the evolution of organic matter, and of the sowing of crops or application of treatments at a specific time of year. The significance of the factor Depth for the four parameters concerned exposed differences in the behavior of the two $\mathrm{A}_{h}$ sub-horizons studied (020 and $20-40 \mathrm{~cm}$ ). The basic difference is more marked changes in the upper sub-horizon, which is subject to heavier tillage, and an increased biological activity in the topmost $20 \mathrm{~cm}$ of soil. Also, the $0-20 \mathrm{~cm} A_{h}$ sub-horizon was that mostly receiving the fertilizers and buried materials used. Finally, there was soil leaching, which occurred largely in the vertical direction.

The significantly different factor levels for the factor Treatment were identified from binary comparisons. Table V shows the results of the least significant difference tests. Consistent with the fact that the organic materials applied to the soil differed in nature and composition, the largest numbers of significant differences between the six Date $\times$ Depth independent variables were those between the mean values of organic matter, total $\mathrm{N}$ and $\mathrm{NO}_{3}^{-}-\mathrm{N}$. On the other hand, the factor Treatment had little discriminating power and influence on the $\mathrm{C} / \mathrm{N}$ ratio and $\mathrm{NH}_{4}^{+}-\mathrm{N}$. The seasonal influence - dealt with above - is illustrated by the data of Table $\mathrm{V}$. Thus, the peak $\mathrm{NO}_{3}^{-}-\mathrm{N}$ levels in the whole $A_{h}$ horizon were obtained in autumn, where the $\mathrm{NH}_{4}^{+}-\mathrm{N}$ levels were minimal. Also in autumn, lupin supplied the largest amounts of $\mathrm{NO}_{3}^{-}-\mathrm{N}$ and some of the lowest $\mathrm{NH}_{4}^{+}-\mathrm{N}$ levels to the whole $A_{h}$ horizon. On the other hand, the rye crop had an impoverishing effect on the topmost $20 \mathrm{~cm}$ of soil, which exhibited the lowest $\mathrm{NO}_{3}^{-}-\mathrm{N}$ levels and highest $\mathrm{NH}_{4}^{+}-\mathrm{N}$ levels. The above-described effects reflected in the mean values obtained; however, the number of significant differences between treatments was small.

The lower $A_{h}$ sub-horizon $(20-40 \mathrm{~cm})$ also reflected the fertilizing effect of the lupin crop; however, the straw exhibited a marked impoverishing effect. These results testify to the ready mineralization of organic $\mathrm{N}$ in the buried lupin green manure, which gave rise to the highest $\mathrm{NO}_{3}^{-}$contents. The
Table VI. Mean parameter values obtained for the soil with each treatment and crop. Identical letters denote non-significant differences $(P=0.05)$.

\begin{tabular}{lccccccccccc}
\hline & & $\begin{array}{c}\text { O.M. } \\
\mathrm{mg} \mathrm{kg}^{-1}\end{array}$ & $\begin{array}{c}\mathrm{N} \\
\mathrm{mg} \mathrm{kg}^{-1}\end{array}$ & $\mathrm{C} / \mathrm{N}$ & $\begin{array}{c}\mathrm{NO}_{3}^{-} \\
\mathrm{mg} \mathrm{kg}^{-1}\end{array}$ & $\begin{array}{c}\mathrm{NH}_{4}^{+} \\
\mathrm{mg} \mathrm{kg}^{-1}\end{array}$ \\
\hline \multirow{4}{*}{ Treatment } & Rye & 76.3 & a & 2.4 & $\mathrm{a}$ & 18.58 & $\mathrm{a}$ & 42.20 & $\mathrm{a}$ & 7.42 & $\mathrm{a}$ \\
& Straw & 80.0 & $\mathrm{a}$ & 2.5 & $\mathrm{a}$ & 18.42 & $\mathrm{ab}$ & 45.22 & $\mathrm{a}$ & 5.85 & $\mathrm{a}$ \\
& Lupin & 85.5 & $\mathrm{~b}$ & 2.8 & $\mathrm{~b}$ & 18.00 & $\mathrm{~b}$ & 61.63 & $\mathrm{~b}$ & 5.60 & $\mathrm{a}$ \\
Crop & Control & 78.6 & $\mathrm{a}$ & 2.5 & $\mathrm{a}$ & 18.38 & $\mathrm{a}$ & 26.40 & $\mathrm{a}$ & 8.53 & $\mathrm{a}$ \\
& Maize & 81.0 & $\mathrm{a}$ & 2.6 & $\mathrm{a}$ & 18.08 & $\mathrm{a}$ & 78.83 & $\mathrm{~b}$ & 5.98 & $\mathrm{ab}$ \\
& Wheat & 80.1 & $\mathrm{a}$ & 2.5 & $\mathrm{a}$ & 18.57 & $\mathrm{a}$ & 44.13 & $\mathrm{c}$ & 5.28 & $\mathrm{~b}$ \\
& Potato & 82.8 & $\mathrm{a}$ & 2.6 & $\mathrm{a}$ & 18.35 & $\mathrm{a}$ & 49.45 & $\mathrm{c}$ & 5.38 & $\mathrm{ab}$ \\
\hline
\end{tabular}

impoverishing effect of rye is also apparent - from its opposite sign, however.

Table VI shows the mean overall values for the two withinsubject factors (Treatment and Crop). The mean values for the four parameters correspond to the individual effects of the factors Treatment and Crop - with the two depths, two sampling dates, three crops and the control in combination in the former case. The second data block in Table VI compares the results obtained at the four levels of the factor Crop for the three organic treatments, and the factors Depth and Date in combination. These results provide valuable global information about each level of Treatment and Crop. Worth special note in this respect are those parameters potentially reflecting the cumulative effect throughout the experiment more faithfully than do the seasonal changes proper; such is the case with $\mathrm{N}$, organic matter and the $\mathrm{C} / \mathrm{N}$ ratio. These three parameters exhibit welldefined trends and expose significant effects of the treatment in spite of the limited sensitivity of the analytical methods used to quantify changes over a short period - particularly from initially high levels such as those found in this study. In contrast with the minimal supply of organic residues from the rye stubble, the incorporation into the soil of a plant material results in the accumulation of organic matter - particularly with lupin, on account of the increased amounts of dry matter it supplies and its increased humus yield. The variation pattern for total $\mathrm{N}$ was similar; however, it is the increased protein contents of the lupin green manure that resulted in the greatest differences with respect to straw, the low nitrogen content of which precludes distinction from the purely impoverishing effect of the rye. As a result of the previous two effects, the $\mathrm{C} / \mathrm{N}$ ratio in the lupintreated plots was considerably lower than in the rye-treated plots, with the buried straw in-between. The increased amount of organic $\mathrm{N}$ and also increased mineralizing biological activity resulting from the use of easily degraded buried plant material influenced the inorganic $\mathrm{N}$ levels; thus, the lupin treatment resulted in the highest nitrate levels and lowest ammonium ion levels, whereas the rye treatment exhibited the opposite effects.

\subsection{Effect on soil nitrate content}

The statistical analysis performed provided not only the mean values described in the previous section, but also the estimated marginal means obtained with the general linear model 


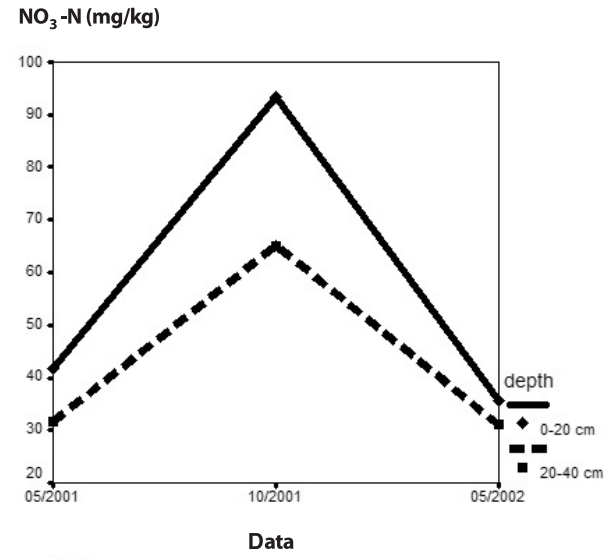

Figure 1. Profile plot of estimated marginal means for $\mathrm{NO}_{3}^{-}$at different dates for the two considered depths. Winter leaching results in minimum of soil nitrate content in spring; whereas high autumn levels are due to organic matter mineralization and crop fertilization. The evolution is more marked in the top layer of soil, with the highest biological activity, and receiving fertilizers and buried materials.

at each factor level. This additional information facilitates the discussion and clearly exposes the interactions between the studied factors in profile plots. The plots that follow correspond to the estimated marginal means (i.e. the result of combining the analysis of variance and regression provided by the general lineal model) and clearly expose any interactions between factors.

Figure 1 illustrates the spatial and temporal variation of the soil nitrate concentration for the treatments as a whole and hence individually for the buried straw, rye cover crop and lupin green manure. The temporal variation included a minimum in spring - prior to crop establishment - followed by a maximum in autumn - after harvest. Such disparate results are the consequence of the cumulative effect of both the applied fertilizer and the mineralization of organic matter, which was stronger during the warm season. The maximum was followed by the typical decrease in $\mathrm{NO}_{3}^{-}-\mathrm{N}$ levels, clearly associated with climate (viz. nitrate leaching from the soil in autumn and winter), and then by the spring minimum.

Nitrate in soil is widely known to be lost via various pathways at the beginning of the rainy season. Under the special conditions of our experiment, however, the $\mathrm{N}$ balance in the studied soil can be simplified by using some approximations. Thus, the virtually flat relief typical of the alluvial surfaces on which the test plots lay precluded heavy runoff. Also, because the soil was sandy loam in its Umbric horizon and clay loam in the Cambic horizon, and both were acid and oligotrophic as inferred from their low effective cation-exchange capacity and percent base saturation (V\%) (Tab. III), one can assume biological activity to be low and hence denitrification to be virtually absent. On the other hand, a mean annual precipitation of $1400 \mathrm{~mm}$ and an average potential evapotranspiration of $612 \mathrm{~mm}$ must result in heavy leaching and sweeping in winter and spring. The extent of leaching will be proportional to the amount of drainage water and the nitrate concentration in it. The fact that leaching is quantitatively much more substantial than

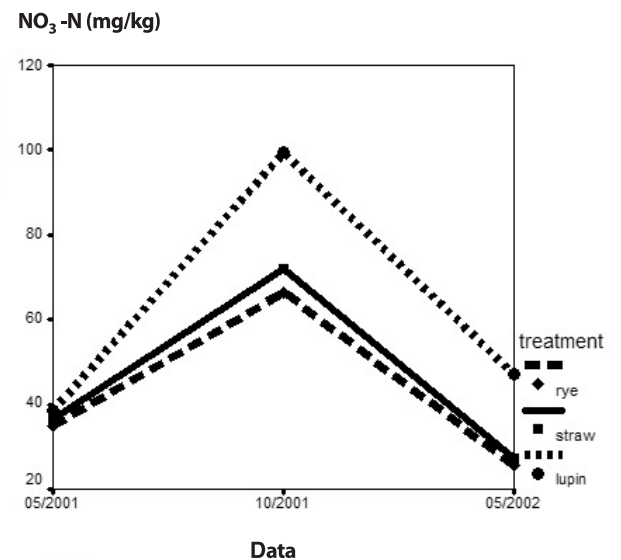

Figure 2. Profile plot of estimated marginal means for soil $\mathrm{N}-\mathrm{NO}_{3}^{-}$ with the different treatments. Buried lupin as green manure provided the highest nitrate levels because of its richness in readily available organic $\mathrm{N}$, as opposed to the blocking effect of straw treatment and the impoverishing due to the rye cover crop.

the other potential mechanisms leading to nitrate losses - and also the only mechanism to be considered in practice - is consistent with the high nitrate contamination levels found in the water resources of the studied region (Vidal et al., 2000a,b).

Disregarding the priming effect may result in the additional mineralization boosting $\mathrm{NO}_{3}^{-}$leaching (Graham et al., 1986). Figure 1 shows the estimated marginal means for the variable $\mathrm{NO}_{3}^{-}$as fitted to the Date $\times$Depth interaction, which was significant at the $P=0.05$ level (Tab. IV). Figure 2, together with the results for this parameter $\left(\mathrm{NO}_{3}^{-}-\mathrm{N}\right)$ corresponding to the mean values in soil with each treatment and as a whole at the four levels of the factor Crop (first data block in Tab. VI), confirms the trapping, sequestering or impoverishing effect of the rye cover crop, even though the differences between the rye and straw treatments were not significant at the $P=0.05$ level (Tab. VI). This protective effect against nitrate contamination is reflected in the fact that, even though the nitrate concentration within the topmost $20 \mathrm{~cm}$ of soil rose to a seasonal maximum in May (Tab. V), the concentration in the subsurface horizon was much lower and underwent much less marked seasonal changes. As can be seen in Table VI, the use of rye as a winter cover crop resulted in both the lowest $\mathrm{NO}_{3}^{-}$concentrations and highest $\mathrm{NH}_{4}^{+}$levels.

The effect reflected in the estimated marginal means provided by the general linear model for the Date $\times$ Treatment interaction (multivariate significance $<0.05$ ) is the so-called "priming effect". As can be seen from Figure 2, such an effect resulted in substantial enrichment with $\mathrm{NO}_{3}^{-}-\mathrm{N}$, particularly with lupin (a legume) by virtue of its increased easily available organic $\mathrm{N}$ content (Tab. II). These results can be interpreted in the light of the mechanisms that govern the mineralization of native organic matter in soil and the edaphic factors that control biomass growth and development (and hence mineralization). In this particular case, the limiting factor for the decomposition of buried straw $(\mathrm{C} / \mathrm{N} \approx 80$, Tab. II) was its own $\mathrm{N}$ content. By contrast, the limiting factor for native organic matter in the soil (C/N for horizon $A_{h}=18.4$ ) was its own $C$ content. Mixing 


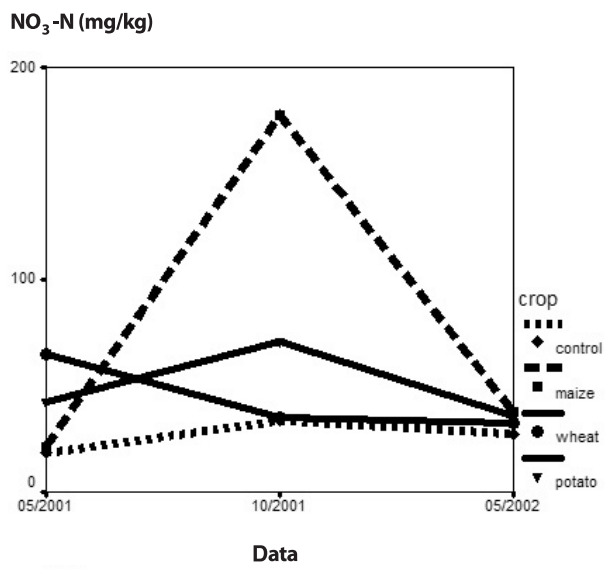

Figure 3. Profile plot of estimated marginal means for $\mathrm{NO}_{3}^{-}$with the different crops. Balance between $\mathrm{N}$ requirements and fertilization incomes for the crops used result in different nitrate contents in soil, especially after harvest. Maize crop generates the highest nitrate levels in autumn, so it is responsible for the highest nitrate losses by winter leaching.

these two substrates suppressed both limiting effects on microbial mass development, thereby accelerating the mineralization of both substrates in relation to the two in isolation. The final outcome of the plant residue burial practice was substantial enrichment with nitrate (especially with the legume, which contains more available $\mathrm{N}$ ).

Similarly, the Date $\times$ Crop interaction depicted in Figure 3 (multivariate significance $P<0.05$ for the variables $\mathrm{C} / \mathrm{N}$ and $\mathrm{NO}_{3}^{-}$) reflects the influence of the different rates of nitrogen fertilizer applied to the crops and the boosting effect on mineralization of the application of $\mathrm{N}$ simultaneously with the burial of plant residues. These results appear to confirm the abovedescribed priming effect, which was enhanced by the simultaneous addition of mineral $\mathrm{N}$ and ultimately resulted in increased mineralization of organic matter (Azam et al., 1994). As the substrate decomposed with time, the effect was reversed and both the contents of humified organic matter and the immobilization of inorganic $\mathrm{N}$ increased beyond a given point. As can also be seen from this profile plot, the marked increase in average nitrate levels predicted by the general linear model (e.g. for the maize crop) cannot be ascribed to the rates of nitrogen fertilizer (whether as $\mathrm{NO}_{3}^{-}-\mathrm{N}, \mathrm{NH}_{4}^{+}-\mathrm{N}$ or both) used. The values recorded in October 2000 can only be due to an increased mineralization rate of organic matter in the soil resulting from application of the nitrogen fertilizer. In addition, the large difference between the residual $\mathrm{NO}_{3}^{-}-\mathrm{N}$ contents of maize and wheat must be the main result of the former being supplied with twice as much fertilizer $\mathrm{N}$ as the latter. Finally, the low $\mathrm{NO}_{3}^{-}-\mathrm{N}$ levels in the control plots during the post-harvest period were a result of their receiving no crop or fertilizer.

\subsection{Evolution of soil total $\mathbf{N}$}

As noted in the Introduction, for cover crops to be effective, they must provide $\mathrm{N}$ for use by the next crop. Although the presence of large amounts of organic $\mathrm{N}$ in soil conceals potential changes in total $\mathrm{N}$ over short periods, the general linear model
TOTAL-N (\%)

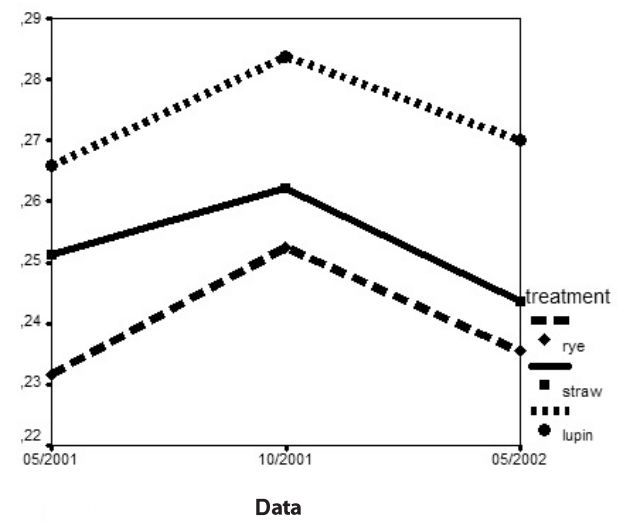

Figure 4. Temporal variation of total $\mathrm{N}$ with each treatment. Large amounts of dried matter buried with lupin treatment and its high $\mathrm{N}$ content results in an increase in total $\mathrm{N}$ of soil. Minimum values correspond to rye cover crop treatment, in which $\mathrm{N}$ accumulated by the crop in winter was mostly removed from the plot with the forage.

used can expose another process involved in N dynamics. Such a process reflects the $\mathrm{N}$ fixation capacity of the soil (Umarov, 1983), provided the individual effects of the other sources of variability are effectively suppressed. The principal limiting factor for the amount of $\mathrm{N}$ that is fixed by soil is the presence of an appropriate source of energy and N. As a rule, the amount of $\mathrm{N}$ fixed (as measured using the Kjeldahl wet method) is only appreciable when the amount applied to the soil is similar to those used in the present tests. Figure 4, which illustrates the Date $\times$ Treatment interaction (multivariate significance $P<$ 0.05 for the variable $\mathrm{NO}_{3}^{-}$), clearly reveals that the buried straw and lupin manure crops provided higher $\mathrm{N}$ final levels than the rye cover crop. The latter provided no gain from potential nonedaphic energy sources. Also worth noting in relation to this figure is the marked increase in the marginal means estimated by the general linear model between May and October (ca. $700 \mathrm{~kg} \mathrm{ha}^{-1}$ total $\mathrm{N}$ ). This can be ascribed to the large amounts of dry matter in the buried green manure $\left(5600 \mathrm{~kg} \mathrm{ha}^{-1}\right)$ and its richness in readily available $\mathrm{N}(3.82 \%)$. The dry matter content of lupin accounts for more than $30 \%$ of the $700 \mathrm{~kg} \mathrm{ha}^{-1}$ increase in total $\mathrm{N}$ between the two sampling dates. Also, one should bear in mind the intrinsic low precision of the Kjeldahl method for determining total $\mathrm{N}$.

Finally, we used the Henin and Dupuis (1945) method to estimate the overall variation of $\mathrm{N}$ in the soil with provision for the simultaneous mineralizing and immobilizing effects of buried plant residues. The results are shown in Table VII. The dry matter content supplied to the soil and the corresponding N content (Tab. II) were used to calculated the amount of $\mathrm{N}$ incorporated in this way (dm-N column in Tab. VII). We also calculated the amount of humus produced from the organic matter supplied and a standard isohumic coefficient $k=0.15$ (Humus column in Tab. VII). The $\mathrm{N}$ content in the humus was in turn calculated from the organic $\mathrm{C}$ content under the assumption of a mutual equilibrium at $\mathrm{C} / \mathrm{N}=18.4$, which was the value corresponding to the $\mathrm{A}_{h}$ horizon (Humus-N column in Tab. VII). The positive differences between the two $\mathrm{N}$ contents expose an 
Table VII. Estimation of the mineralizing-immobilizing effect of the buried plant residues.

\begin{tabular}{|c|c|c|c|c|c|c|}
\hline & $\begin{array}{l}\text { d. } \mathrm{m} . \\
\text { t ha }^{-1}\end{array}$ & $\begin{array}{l}\text { N-d.m. } \\
\text { t ha }^{-1}\end{array}$ & $\begin{array}{l}\text { Humus } \\
\mathrm{t} \mathrm{ha}^{-1}\end{array}$ & $\begin{array}{c}\text { N humus } \\
\mathrm{t} \mathrm{ha}^{-1}\end{array}$ & $\begin{array}{c}\mathrm{C} / \mathrm{N} \\
\text { humus }\end{array}$ & $\begin{array}{c}\text { variation } \mathrm{N} \\
\mathrm{t} \mathrm{ha}^{-1}\end{array}$ \\
\hline Straw $4 \mathrm{t} \mathrm{ha}^{-1}$ & 3.884 & 0.023 & 0.583 & 0.090 & 18.4 & +0.067 \\
\hline Straw $5 \mathrm{t} \mathrm{ha}^{-1}$ & 4.855 & 0.025 & 0.728 & 0.109 & 18.4 & +0.084 \\
\hline Lupin & 5.538 & 0.212 & 0.443 & 0.014 & 18.4 & -0.198 \\
\hline
\end{tabular}

immobilizing or blocking action associated with the typical depressing effect of a buried plant residue such as cereal straw. On the other hand, the negative values of the difference expose the fertilizing effect of lupin.

\section{CONCLUSION}

Based on the significant effect $(P<0.05)$ of the factor Treatment, this three-year field study of a humid region severely affected by nitrate contamination in its drinking water resources reveals that the application of a rye cover crop and using buried straw during the post-harvest period reduces the nitrate concentration in the topmost $20 \mathrm{~cm}$ of soil. If one considers soil depth and the seasonal variation in combination, then the influence of the factor Treatment exceeds the discriminating power of the factor Crop for organic matter, $\mathrm{N}$ and the $\mathrm{C} / \mathrm{N}$ ratio; the response is reversed with $\mathrm{NO}_{3}^{-}-\mathrm{N}$ and $\mathrm{NH}_{4}^{+}-\mathrm{N}$. The significance values $(P<0.05)$ for the multivariate comparisons of the factor Depth on organic matter, total $\mathrm{N}$ and $\mathrm{NO}_{3}^{-}-\mathrm{N}$, and those for the factor Date, which was significant $(P<0.05)$ on all the parameters, clearly exposes the strong influence of both the seasonal character and the preventive and corrective farming practices. Also, the repeated measurements general linear model applied to the results reveals that the sequestering or impoverishing effect of $\mathrm{NO}_{3}^{-}-\mathrm{N}$ in the rye cover crop exceeds the immobilizing effect of a plant residue with a high $\mathrm{C} / \mathrm{N}$ ratio (e.g. wheat straw) applied to soil. Also, buried lupin green manure exhibits an $\mathrm{N}$ fertilizing outcome as opposed to the immobilizing outcome of a buried straw crop - whatever its application rate. The Date $\times$ Treatment and Date $\times$ Crop interactions, both with a multivariate significance $P<0.05$ for $\mathrm{NO}_{3}^{-}$, reveal a priming effect that is enhanced by the simultaneous application of mineral $\mathrm{N}$ and the incorporation of plant residues into the soil.

Acknowledgements: The authors are grateful to the Consellería de Educación y Ordenación Universitaria de la XUNTA de Galicia (Spain) for funding this research within the framework of Project XUGA-29104B94.

\section{REFERENCES}

Addiscott T.M., Whitmore A.P., Powinson D.S. (1991) Farming fertilizers and the nitrate problem, $\mathrm{CAB}$ international, Wallingford, Oxon.

Andrén O., Paustian K. (1987) Barley straw descomposition in the field: a comparison of models, Ecology 68, 1190-1200.

Andrén O., Steen E., Raghai K. (1992) Modelling the effects of moisture on barley straw and root descomposing in the field, Soil Biol. Biochem. 24, 727-736.
Azam F., Simmons F.W., Mulvaney R.L. (1994) The effect of inorganic nitrogen on the added nitrogen interaction of soil in incubation experiments, Biol. Fert. Soils 18, 103-108.

Bingemann C.W., Varner J.E., Martin W.P. (1953) The effect of the addition of organic materials on the descomposition of an organic soil, Soil Sci. Soc. Am. Proc. 17, 34-38.

Brinsfield R.B., Staver K.W. (1992) Use of cereal grain cover crops for reducing groundwater nitrate contamination in the Chesapeake Bay region, Commun. Soil Sci. Plan Anal. 23, 2103-2109.

C.E.E. (1991) Protection des eaux contre la pollution par les nitrates à partir de sources agricoles, in: Journal Officiel $n^{\circ} \mathrm{L} 375$, Bruxelles, pp. 1-8.

Chapman S.J. (1997) Carbon substrate mineralization and sulphur limitation, Soil Biol. Biochem. 29, 115-122.

Dalemberg J.W., Jager G. (1989) Priming effect of small glucose additions to ${ }^{14} \mathrm{C}$-labeled soil, Soil Biol. Biochem. 13, 219-223.

Doryland C.J. (1916) The influence of energy material upon the relation of soil microorganisms to soluble plant food, N. Dak. Agr. Exp. Sta. Bul. 116 .

FAO (1997) Control of water pollution from agriculture, FAO irrigation and drainage paper 55, Rome.

FAO (1998) World reference base for soil resources, paper 84, Rome.

Francis G.S., Haynes R.J., Williams P.H. (1994) Nitrogen mineralization, nitrate leaching and crop growth after ploughing-in leguminous and non-leguminous grain crop residues, J. Agr. Sci. 123, $81-87$.

Graham J.P., Ellis F.B., Christian D.G., Cannell R.Q. (1986) Effects of straw residue on the establishment, growth and yield of autumn sown cereals, J. Agric. Eng. Res. 33, 39-49.

Haynes R.J. (1986) The descomposition process: mineralization, immobilization, humus formation, and degradation, in: Cameron K.C., Goh K., Sherlock R. (Eds.), Mineral nitrogen in the plant-soil system, Academic Press, London, pp. 100-126.

Henin S., Dupuis M. (1945) Essai de bilan de la matiére organique des sols, Ann. Agron. 15, 161-172.

Holderbaum J.F., Decker A., Meisinger F.R., Vough R. (1990) Fallseeded legume cover crops for no-tillage corn in the humid east, Agron. J. 82, 117-124.

Jansson S.L. (1958) Tracer studies on nitrogen transformations in soil with special attention to mineralization-immobilization relationships, Kongliga Lantbrukshogskolans Annaler. 24, 101-361.

Keeney D.R., Nelson D.V. (1982) Nitrogen: inorganic forms, in: Miller A.L., Keeney D.R. (Eds.), Methods of Soil Analysis. Part 2, Chemical and Microbiological Properties, ASA and SSSA, Agron. No. 9, Madison, WI, pp. 643-698.

Klute A. (1986) Water retention: laboratory methods, in: Klute A. (Ed.), Methods of soil analysis. Part 1. Physical and mineralogical methods, 2nd ed., Agronomy 9, pp. 635-662.

Konobeka S., Sabbe W.E., Mauromous A. (1997) Carbon descomposition kinetics and nitrogen mineralization from corn, soybean and wheat, Commun Soil Sci. Plan Anal. 28, 1359-1373.

Kuderayoz V.N., Kuznetsova T.V., Bashkin V.N. (1987) An investigation of the effect and residual effect of ${ }^{15} \mathrm{~N}$-labelled ammonium nitrate in a field experiment on grey forest soil, Agrokhimiya 9, 3-7.

Kuzyakov Y., Friedel J.K., Stahr K. (2000) Review of mechanisms and quantification of priming effects, Soil Biol. Biochem. 32, 14851498.

Leon M., Laine P., Ourry A., Boucaud J. (1995) Increased uptake of native soil nitrogen by roots of Lolium multiflorum after nitrogen fertilization is explained by a stimulation of the uptake process itself, Plant Soil 173, 197-203.

Lohnis F. (1926) Nitrogen avaibility of green manure, Soil Sci. 22, $253-$ 290. 
López A. (2001) Caracterización del suelo de las parcelas, in: Prácticas agronómicas de control de la contaminación agraria derivada de la fertilización. Efectos de sobre la dinámica de nutrientes, $\mathrm{PhD}$ Thesis, University of Santiago de Compostela, La Coruña, Spain, pp. 110-115.

McCullagh P., Nelder J.A. (1983) Generalized Linear models, Chapman \& Hall, London.

Nelson D.W., Sommers L.E. (1982) Total carbon, organic carbon and organic mater, in: Methods of soil analysis, Part 2, 2nd ed., Am. Soc. Agron., Soil Sci. Soc. Am., Madison.

Ocio J., Martínez J., Brookes P.C. (1991) Contribution of straw-derived $\mathrm{N}$ to total microbial biomass $\mathrm{N}$ following incorporation of cereal straw to soil, Soil Biol. Biochem. 17, 655-659.

Paramasivan S., Alva A.K. (1997) Leaching of nitrogen from controlreleased fertilizers, Commun. Soil Sci. Plan Anal. 28, 1663-1674.

Peech M., Alexander L. (1947) Methods of soil analysis for soil fertility investigations, in: Cir. 757, US Department Agriculture (Ed.), Washington.

Powlson D.S., Brookes P.C., Christensen B.T. (1988) Measurement of soil microbial biomass provides an early indication of changes in total soil organic matter due to straw incorporation, Soil Biol. Biochem. 19, 159-164.

Sempere A., Olive J., Ramos C. (1993) Simple determination of nitrate in soils by second derivative spectroscopy, J. Soil Sci. 44, 633639.

Staver K., Brinsfield R.B. (1991) Effect of cereal grain winter cover crops on surface water pollutant transport from Coastal Plain corn production systems, in: Hargrove W.L. (Ed.), Cover crops for clean water, Soil and Water Conservation Society, Ankeny, Iowa, pp. 50-52.

Tiessen H., Bettany J.R., Steward J.W. (1981) An improved method for the determination of carbon in soils and soil extracts by dry combustion, Commun. Soil Sci. Plant Anal. 12, 211-218.

Umarov M.M. (1983) Associative nitrogen fixation (specific features, productivity, importance for nitrogen balance of soils), Moscow University Press, Moscow.

USDA (1999) Soil Taxonomy, a basic system for making and interpreting soil surveys, 2nd ed., Agriculture Handbook No. 436, Washington.

Van Gestel M., Merckx R., Vlassak K. (1993) Microbial biomass responses to soil drying and rewetting: the fate of fast-and slowgrowing microorganisms in soils from different climates, Soil Biol. Biochem. 25, 109-123.

Vidal M., López A., Santoalla Mª.C., Valles V. (2000a) Factor analysis for the study of water resources contamination due to the use of livestook slurries as fertilizer, Agr. Water Manage. 45, 1-15.

Vidal M., Melgar J., López A., Santoalla Ma .C. (2000b) Spatial and temporal hydrochemical changes in underground waters under the contaminating effects of fertilizers and waste water, J. Environ. Manage. 60, 215-225.

Widdowson F., Penny A., Darby R., Hewitt M.V. (1987) Amounts of nitrate- $\mathrm{N}$ an ammonium- $\mathrm{N}$ in soil from autumn to spring, under winter wheat and their relationship to soil type, sowing date, previous crop and $\mathrm{N}$ uptake at Rothamsted, Woburn and Saxmundham, J. Agr. Sci. 108, 73-95. 